\title{
Seroprevalence of Hepatitis B among Blood Donors in Mbuji-Mayi, "Case of Dipumba General Hospital” (DRC)
}

\author{
Ciamala Mukendi Paul1* ${ }^{*}$ Kanyiki Katala Moise2, Banza Ndala Deca Blood2, \\ Ntumba Mukendi Kennedy¹, Jean Mukendi Mukendi Réne', Kolela Kolela Alain1, \\ Kaya Tompa Brigitte1, Gabriel Mbuyi Lubemba', Bukasa Lumbayi Laurent ${ }^{1}$, \\ Kabamba Nzaji Michel ${ }^{3}$
}

${ }^{1}$ Department of Teaching and Administration in Nursing, Nursing Section, Higher Institute of Medical Techniques of
Mbuji-Mayi, Mbuji-Mayi, Democratic Republic of Congo
${ }^{2}$ Department of Epidemiology, Community Health Section, Higher Institute of Medical Techniques of Mbuji-Mayi, Mbuji-Mayi,
Democratic Republic of Congo
${ }^{3}$ Department of Public Health, Faculty of Medicine, University of Kamina, Kamina, Democratic Republic of Congo
Email: * paultshamala@gmail.com

How to cite this paper: Paul, C.M., Moise, K.K., Blood, B.N.D., Kennedy, N.M., Réne, J.M.M., Alain, K.K., Brigitte, K.T., Lubemba, G.M., Laurent, B.L. and Michel, K.N. (2017) Seroprevalence of Hepatitis B among Blood Donors in Mbuji-Mayi, "Case of Dipumba General Hospital” (DRC). Open Access Library Journal, 4: e3503. https://doi.org/10.4236/oalib.1103503

Received: March 8, 2017

Accepted: March 27, 2017

Published: March 31, 2017

Copyright $\odot 2017$ by authors and Open Access Library Inc.

This work is licensed under the Creative

Commons Attribution International

License (CC BY 4.0).

http://creativecommons.org/licenses/by/4.0/

\section{(c) () Open Access}

\begin{abstract}
Seroprevalence among blood donors is a major public health problem, both in developed and developing countries, in its magnitude. The aim of this study was to determine the seroprevalence of hepatitis B in blood donors. This is a descriptive study carried out in the city of Mbuji-Mayi at the General Hospital of Dipumba in blood donors (family, volunteer and remunerated) recorded from 01/to31/December 2016; the data were collected in a transverse fashion. The following observations were made: During the study period, 1584 blood donors were registered. After analyzing the data, the seroprevalence of hepatitis B in blood donors was $2.2 \%, 77.8 \%$ were male (sex ratio M/F 3.5 and voluntary donors were $50.4 \%$.
\end{abstract}

\section{Subject Areas}

Hematology, Public Health

\section{Keywords}

Seroprevalence, Hepatitis B, Donors, Mbuji-Mayi

\section{Introduction}

Blood transfusion is a life-saving intervention that plays an essential role in the 
care of patients in health care systems. Hepatitis B virus (HBV) infection is a global public health problem, and an estimated two billion people worldwide have been infected over the course of their lives. HBV is a DNA virus belonging to the Hepadnaviridae family and the genus Orthohepadnavirus, and its reservoir is human [1].

Tounkara A., Sarro Y.S. and Kristensen S. report that despite progress in the fight against human immunodeficiency virus (HIV) and hepatitis B (HBV) and $\mathrm{C}(\mathrm{HCV})$ viruses, these pandemics continue to be a problem that deserves special attention in sub-Saharan Africa, which remains the most affected region of the world [2].

In France, monitoring of HBs antigen in blood donors from 1991 to 2003 showed a drop in the prevalence of HBsAg from 5.3 to 1.8 per 10,000 donations. In new donors, the prevalence of HBsAg increased from 28.4 to 11.7 per 10,000 donations, a positive donation rate divided by 2.4 in 13 years. For known donors, this rate was divided by 72 , with a prevalence that decreased from 1.45 to 0.02 per 10,000 donations [3] [4]. In Guadeloupe the frequency of occult hepatitis $\mathrm{B}$ in the blood donor population is low; it is between $0.4 \%$ and $3.1 \%$ [5].

In developing countries or economies in transition, many people die because of lack of safe blood, and, even in some urban healthcare facilities. [6] In Mali, in a study of seroprevalence of virus Hepatitis B among blood donorsporting the HBsAg was 5.3\% [7]. By against Cameroon, Magloire Biwole S. Jeatsa Gapdo and Mbangue reported a prevalence of 5.3\% [8].

In the Democratic Republic of Congo, hepatitis B infection, particularly by transfusion, remains a major public health problem, as the geographic distribution of the prevalence of hepatitis B Different from that of other African countries, the seroprevalence of chronic carriage of the Hbs antigen varies between 8 and $15 \%$ in the general population [9].

The results of Kabamba Nzaji Michel and Kabyla Ilunga Benjamin showed that the overall seroprevalence of HIV, HBV, HCV and syphilis was $2.9 \%, 1.6 \%$, $0.2 \%$ and $0.2 \%$, respectively, in Kamina [10], while Namululi B.A., Guerrieri C., and Dramaix M.W. reported prevalence in Bukavu blood donors of $1 \%$ for HIV and $3.7 \%$ for Ag HBs [11].

The province of Kasai Oriental in general and in particular the city of Mbujimayi our research community is not spared by this problem because we have observed that the use of blood transfusion constitutes a therapeutic way to meet certain needs of the care of patients.

The aim of this study is to determine the blood donor profile and the prevalence of the hepatitis B virus in the city of Mbuji-Mayi in order to contribute to safe transfusion.

\section{Material and Methods}

We performed a retrospective cross-sectional descriptive study of serum hepatitis B markers in blood donors. The study was spread over a period of 12 months, 
from January 1 to December 31, 2016.

Our target population is made up of all voluntary, family and remunerated blood donors who have consulted Dipumba General Hospital during 2016. Consisting of 1584 donors, our sampling is exhaustive.

Included in the study are all blood donors (volunteers, family members and remunerated) registered at the blood bank of the Dipumba General Reference Hospital (Mbuji-Mayi). The serodiagnosis on each donation was performed by Determination TM HBs Ag Abbott reagents for HBV. A recording grid was used to collect the data from the study.

We have encoded the data with the Excel software but the analysis was done using the SPSS 20 software. The descriptive analysis was carried out by calculating the proportions for the qualitative variables. The study variables are age, sex, donor categories and HBs serology.

The descriptive analysis was carried out by calculations the proportions for the qualitative variables and the different frequency comparisons were encrypted using the Chi-square test of Pearson and the Fisher test if necessary. We set the statistical significance threshold at $\mathrm{p}<0.05$.

This study was approved by related ethics committee besides and donors sign informed consent and have a whole understanding of this study. Our study had no binding character. Any information collected from donors has been and will remain confidential. Similarly, the names of participants will remain confidential and will not be mentioned in the presentation of results or associated to results in any way whatsoever. They will also be disclosed to any third party.

\section{Results}

Table 1 indicates that the prevalence of ' hepatitis B in blood donors is $2.2 \%$.

It appears from Table 2 that the majority of donors in our study was 19 to 35 years or $60.4 \%$; $77.8 \%$ were male (sex ratio M/F 3.5 ); and $76.9 \%$ of married. Note that $50.4 \%$ of donors were our series family,

The results in Table 3 show that the proportions of HBs positive are high among males (2.4\%) compared to females, the same observation is made to unmarried or donors (3.8\%). Compared to the categories of blood donors, the conclusion is that the proportions of ' positive HBs are elevated in family donors or paid either $(2.3 \%)$, there are donors older than 35 years with $(2.5 \%)$ without this being statistically significant. These results show a statistically significant association between the vital donor and positive HBs because the value of $\mathrm{p}$-value is less than $5 \%$.

Table 1. Prevalence of hepatitis B in donors.

\begin{tabular}{ccc}
\hline Case & Effective & Percentage \\
\hline Negative & 1549 & $97.8 \%$ \\
Positive & 35 & $2.2 \%$ \\
Total & 1584 & $100 \%$ \\
\hline
\end{tabular}


Table 2. Breakdown of cases by sociodemographic characteristics of the donor.

\begin{tabular}{ccc}
\hline Characteristics & Effective $\mathbf{n}=\mathbf{1 5 8 4}$ & Percentage \\
\hline Age & & \\
19 to 35 & 957 & $60.4 \%$ \\
Less than or equal to 18 years & 101 & $6.4 \%$ \\
Above 35 years & 526 & $33.2 \%$ \\
Sex & & \\
Female & 352 & $22.2 \%$ \\
Male & 1232 & $77.8 \%$ \\
Total & 1584 & $100 \%$ \\
Marital status & & \\
Single & 362 & $22.9 \%$ \\
Divorced & 4 & $0,3 \%$ \\
Married & 1218 & $76.9 \%$ \\
Donor Category & & $22 . \%$ \\
Volunteer & 349 & $50.4 \%$ \\
Family & 798 & $27.6 \%$ \\
Paid & 437 & \\
\hline & & $22.4 \%$ \\
\hline
\end{tabular}

Table 3. Association between results HBs and characteristics of the donor.

\begin{tabular}{|c|c|c|c|c|c|}
\hline \multirow{2}{*}{ Characteristics } & \multicolumn{2}{|c|}{ HBs } & \multirow{2}{*}{ odds Ratio } & \multirow{2}{*}{ IC (95\%) } & \multirow{2}{*}{$\mathbf{P}$} \\
\hline & Negative & Positive & & & \\
\hline \multicolumn{6}{|l|}{ Sex } \\
\hline Female & $346(98.3 \%)$ & $6(1.7 \%)$ & 1390 & {$[0.573-3.375]$} & 0.464 \\
\hline Male & $1203(97.6 \%)$ & $29(2.4 \%)$ & & & \\
\hline \multicolumn{6}{|l|}{ Marital status } \\
\hline Married & $1197(98.3 \%)$ & $21(1.7 \%)$ & 2267 & {$[1.141-4.505]$} & 0.016 \\
\hline Not married & $352(96.2 \%)$ & $14(3.8 \%)$ & & & \\
\hline \multicolumn{6}{|l|}{ Categories donors } \\
\hline Volunteer & $343(98.3 \%)$ & $6(1.7 \%)$ & 1375 & {$[0.566-3.338]$} & 0.480 \\
\hline Family or paid & $1206(97.7 \%)$ & $29(2.3)$ & & & \\
\hline Age & & & & & 0.472 \\
\hline 19 to 35 & $942(98.4 \%)$ & $15(1.6 \%)$ & & & \\
\hline Less than or equal to 18 years & $99(98.0 \%)$ & $2(2.0 \%)$ & & & \\
\hline Above 35 years & $513(97.5 \%)$ & $13(2.5 \%)$ & & & \\
\hline
\end{tabular}

\section{Discussion}

Indeed the results of our studies have shown that the prevalence of Hepatitis B among blood donors is $2.2 \%$. HBV seroprevalence in this study is less than that found in our country, 3.63\% in 2005 in Kinshasa, [12] than 3\% in Kisangani in 
2004 [6] and Morocco 2.81\% [13] to that found in Kinshasa-East (9.2\%) [14] in 2001, 3.7\% for HBsAg among blood donors in Bukavu and the rate found by other African studies such as the Ivory Coast 12.5\% [15] and Ghana 8.2\% [16].

However, our observations are similar to those of Kamina and Lubumbashi where the porting of antigen HBs was $1.6 \%$ respectively [10] and $2.67 \%$ [17]. This difference can be attributed to differences in methodologies, in fact we worked on whole population donors (replacements and volunteers) while other authors have worked solely on volunteer blood donors and some authors used confirmatory tests while we used the test for serology.

The majority of donors in our study was 19 to 35 years or $60.4 \%$. Which diverges with Kamina where the tranche age represented $57.1 \%$ [10]. This cans $s$ due to the fact that in low- and middle-income youth are more likely to donate blood than in high-income countries [17]

Regarding found predominantly male $77.8 \%$ (sex ratio M/F 3.5). These results are similar to those of Ngama Kakisingi Christian, Mukuku Olivier, Serge et al Kapend Matanda who Lubumbashi a majority consisting of male donors (83.14\%) with a sex ratio M/F 4.93 [17]. These results are consistent with those established by other authors who believe that generally according to some traditional African beliefs or convictions, man would usually healthier than women [18] [19] [20]. The observations of our study support this assertion.

In terms of category, family donors were the majority (50.4\%). These results contrast with those of Kamina where the authors had reported $51.4 \%$ of volunteer blood donors [10], But similar to those of Lubumbashi where the category, family donors accounted for $62.27 \%$ [19]. Note that 72 countries among which the Democratic Republic of Congo, collecting more than $50 \%$ of their blood supplies through the gift of a family member/compensation or paid donors [21].

The results of this study revealed a statistically significant association between donor status and HBs positive $(P=0.016)$. This is explained by the fact that the majority of the donors in our study are married, and the sexual voice is a mode of transmission of Hepatitis B [22].

\section{Conclusions}

The prevalence of hepatitis B in blood donors is a public health issue that deserves special attention. In the objective to determine that-one in the city presented the study led to the findings that the prevalence is $2.2 \%$.

The results of this analysis suggest that the seroprevalence of $\mathrm{HBV}$ and $\mathrm{Mbu}-$ ji-Mayi is comparable to that observed in other city of the DRC.

Moreover, the majority of blood donors in this study is male $(77.8 \%)$. The sex ratio was 3.5. The slice of age 19 to 35 years is $60.4 \%, 76.9 \%$ of donors were married and $50.4 \%$ were volunteers.

However, another study is important to determine the seroprevalence of $\mathrm{He}$ patitis $\mathrm{C}$ in donors in the city of Mbuji-Mayi. 


\section{References}

[1] Heymann, D.L. (2004) Control of Communicable Diseases Manual. APHA, Washington DC, 253-261.

[2] Tounkara, A., Sarro, Y.S., Kristensen, S., et al. (2009) Seroprevalence of HIV/HBV Co-Infection in Blood Donors Malian. Journal of the International Association of Physicians in AIDS Care, 8, 47-51.

[3] Pillonel, J. and Laperche, S. (2001) Monitoring of Markers' Infection with HIV, HTLV and Hepatitis B and C Chez Blood Donors in France from 1991 to 2000. Bulletin Epidémiologique Hebdomadaire, 47, 207-209.

[4] Pillonel, J., Marrec, N., Girault, A., David, D. and Laperche, S. (2005) Epidemiological Surveillance Homologous Blood Donors in France and Residual Risk between 2001 and 2003. Transfusion Clinique et Biologique, 12, 239-246.

[5] Manoliu, C.L., Cleril, M., Jasmin, B., Langou, T., Pincemail, P., Bolo, F. and Guilhem, I. (2015) Genetic Diversity of the Virus Hepatitis B among Blood Donors in Guadeloupe Posters/Transfusion. Clinique et Biologique, 20, 295-369.

[6] Batina, A., Kabemba, S. and Malengela, R. (2007) Infectious Markers among Blood Donors in Democratic Republic of Congo. Revue Médicale de Bruxelles, 28, 145 149.

[7] Koné, M.C., Sidibé, Mallé, K.K., Beye, S.A., Lurton, G., Dao, S., Diarra, M.T. and Dao, S. (2012) Seroprevalence of the Virus Human Immunodeficiency Virus and Hepatitis B and C among Blood Donors in Segou (Mali). Medicine and Tropical Health, 22, N8.

[8] Sida, M.B., Gapdo, J., Mbangue, M., Essola, J., Leundji, H. and Dissongoii, J. (2015) Prevalence of HBC Antibodies in Blood Donors Ag Hbs Negatives to Laquintinie Hospital Doua Home. The Journal of Medicine and Health Sciences, 16. http://www.hsd-fmsb.org/index.php/hsd/article/view/499/0

[9] CNTS (2005) 6th Scientific Days of Blood Transfusion. DRC, Kinshasa.

[10] Michel, K.N. and Benjamin, I.K. (2013) Prévalence des marqueurs infectieux chez les donneurs de sang en milieu rural. Cas de l'hôpital général de référence de Kamina. Santé Publique, 25, 213-217.

http://www.cairn.info/revue-sante-publique-2013-2-page-213.htm

[11] Namululi, B.A., Guerrieri, C. and Dramaix, M.W. (2015) Prevalence and Incidence of HIV and the Hepatitis B in Blood Donors and Estimation of the Risk of Transmission of HIV and HBV Virus through Blood Transfusion. A Study in the General Provincial Referral Hospital in Bukavu, Democratic Republic of Congo.

[12] Kapila, N.G., Van Der Veken, W., Ruppol, S. and Mulumba, A. (2005) Contribution of Belgian Technical Cooperation in Blood Transfusion in Republic of the Congo from 2002 to 2004. TransfusClinBiol, 12, S1-S43.

[13] Elect Dokekias, A., Okandze-Elenga, J.P., Dzia Lepfoundzou, A. and Parra, H.J. (2002) Prevalence of Major Viral Markers in Blood Donors Brazza City. Gas Transfus, 4-6.

[14] Mbendi, N.C., Longo-Mbenza, B., Mbendi Nsukini, S., Muyembe Tamfum, J.J., Sitakipuanza Nanituma, H. and Vangu Ngoma, D. (2001) Prevalence of HIV and 1 HBsAg among Blood Donors. Residual Contamination in Recipients of Blood in Kinshasa-East, Democratic Republic of Congo. Tropical Medicine, 61, 139-142.

[15] Kra, O., Dri, N., Ehui, E. and Ouattara, B. (2007) Prevalence of HBs Antigen in Blood Donors at the Regional Blood Transfusion Center in Bouaké (Côte d'Ivoire) in 2001. Bulletin de la Société de Pathologie Exotique, 100, 127-129. 
[16] Allain, J.P., Candotti, D., Soldan, K., Sarkodie, F., Phelps, B., Giachetti, C., et al. (2003) The Risk of Hepatitis B Virus Infection by Transfusion in Kumasi, Ghana. Blood, 101, 2419-2425.

[17] Christian, N.K., Olivier, M., Kapend, S.M., et al. (2016) Epidemiological Profile and Prevalence of Blood Donors to the University Clinics in Lubumbashi, Democratic Republic of Congo. Pan African Medical Journal, 23, 175.

[18] Rajab, J.A., Muchina, W.P., Orinda, D.A. and Scott, C.S. (2005) Blood Donor Hematology Parameters in Two Regions of Kenya. East African Medical Journal, 346, 530-536.

[19] Nébié, K.Y., Olinger, C.M., Kafando, E., Dahourou, H., Diallo, S., Kientega, Y., Domo, Y., Kienou, K., Ouattara, S., Sawadogo, I., Ky, L. and Muller, P.O. (2007) Lack of Knowledge among Blood Donors in Burkina Faso (West Africa); Potential Obstacle to Transfusion Security. Transfusion Clinique et Biologique, 14, 446-452.

[20] Noubiap, J.J., Joko, W.Y., Nansseu, J.R., Tene, U.G. and Siaka, C. (2013) Sero-Epidemiology of Human Immunodeficiency Virus, Hepatitis B and C Viruses, and Syphilis Infections among First-Time Blood Donors in Edea, Cameroon. International Journal of Infectious Diseases, 17, 832-837.

[21] WHO (2016) Blood Safety and Supply of Blood. http://www.who.int/mediacentre/factsheets/fs279/fr/

[22] World Health Organization (2010) Screening of Infections Transmitted by Transfusion in Blood Donations. WHO, Geneva.

Open Access Library

Submit or recommend next manuscript to OALib Journal and we will provide best service for you:

- Publication frequency: Monthly

- 9 subject areas of science, technology and medicine

- Fair and rigorous peer-review system

- Fast publication process

- Article promotion in various social networking sites (LinkedIn, Facebook, Twitter, etc.)

- Maximum dissemination of your research work

Submit Your Paper Online: Click Here to Submit

Or Contact service@oalib.com 